\title{
Dental Medicine Students Perception on the Effectiveness of Problem Based Learning (PBL) Class Using Online Learning Method
}

\author{
Nicholas Ezra ${ }^{1}$, Aryo Dwipo Kusumo ${ }^{2,3}$, Kamilia Fahmi Ag ${ }^{1}$, Fathimah Hanan ${ }^{1}$, \\ Naurah Nabilah Pramaztri ${ }^{1}$, Leila Isyafitri ${ }^{1}$, Mohammed Alaqsha Brysoul Ceson ${ }^{1}$ \\ ${ }^{1}$ Undergraduate Student, Faculty of Dental Medicine, Universitas Airlangga, ${ }^{2}$ Graduate Student of Health \\ Administration and Policy, Faculty of Public Health, Universitas Airlangga, ${ }^{3}$ Department of Dental Public Health, \\ Faculty of Dental Medicine, Universitas Airlangga
}

\begin{abstract}
Background: The main concern of universities is regarding the quality and effectiveness of education. A total of 32 dentistry faculties in Indonesia have implemented Problem Based Learning (PBL) classes in their learning curriculum. Some dentistry faculties have actively used student-centered learning method, and are no longer teacher-centered. According to the results of the 2017 Indonesian Internet Service Providers Association, the prevalence for Indonesian (Undergraduate/Diploma) students as Internet users reached $79.23 \%$.
\end{abstract}

Purpose: To describe the perception of Universitas Airlangga Faculty of Dental Medicine students on the effectiveness of the Problem Based Learning (PBL) class using the Online Learning method.

Method: Data was collected from the distribution of questionnaires to students of Universitas Airlangga, Faculty of Dental Medicine semesters 1, 3, 5, and 7. Then a descriptive statistical test was conducted.

Results: The percentage of respondents who considered effective Problem Based Learning (PBL) classes using online learning method was $52.4 \%$, very effective at $5.8 \%$, very ineffective at $2.9 \%$, no opinion at $14.6 \%$, and ineffective at $24.3 \%$.

Conclusion: The majority of Universitas Airlangga Faculty of Dental Medicine students have an effective perception of the Problem Based Learning (PBL) class using the Online Learning method.

Keywords: Effectivity perception, Problem Based Learning (PBL), online learning, dental medicine students.

\section{Introduction}

The quality and effectiveness of education is the

\section{Corresponding Author:}

\section{Aryo Dwipo Kusumo}

Graduate Student of Health Administration and Policy, Faculty of Public Health Universitas Airlanggaand Department of Dental Public Health, Faculty of Dental Medicine, Universitas Airlangga, Prof. Dr. Moestopo Street No. 47

Phone Numbers: (+6231) 5030255, 5020256,

Facsimile Numbers: $(+6231) 5020256$

e-mail: kusumoaryo.450@gmail.com main concern of universities. Lately, several dentistry schools have actively used student-centered learning method, no longer teacher-centered ${ }^{1}$. A total of 32 dentistry faculties in Indonesia have established PBL classes in their learning curriculum. The problem faced by students at this time is the lack of use of technology and only refers to Problem Based Learning. Thus, the knowledge gained is limited. According to the results of the Indonesian Internet Service Providers AssociationResearch, internet user penetration based on the latest education level in 2017 , the prevalence for Indonesian students reached $79.23 \%$.

The Problem Based Learning (PBL) model is one of the learning models that leads to problem solving 
which is expected to hone students' critical thinking skills $^{2}$. Problem Based Learning (PBL) has actually been developed more than 40 years ago as a reaction to the problems and limitations of traditional teaching approaches ${ }^{1}$. PBL is expected to help students to develop thinking skills and problem solving skills ${ }^{2}$.Students with problem based learning learning strategies have greater motivation and learning strategies compared to education using collaborative learning learning strategies ${ }^{3}$.

In the Indonesian Dentist Competency Standards, graduates of the dentistry study program are prepared to produce competent and skilled and professional human resources in providing services to the community ${ }^{4}$. For this reason, universities must be able to shape the mindset of students.

\section{Material and Method}

The research method is the path or way taken in connection with research conducted and has systematic steps. Research method can be interpreted as a scientific way to obtain valid data with the aim to be found, developed, and proven, a knowledge that can be used to understand, solve, and anticipate problems ${ }^{5}$. The research method includes research procedures and techniques. By mastering research method, not only can solve various research problems, but also can develop the field of science that is involved.

Research design or design is a plan about collecting, processing and analyzing data systematically and directed so that research can be carried out efficiently and effectively in accordance with its objectives ${ }^{6}$. Meanwhile, according to Pressman, the design is a series of procedures to translate the results of the analysis of a system into a discussion of programming to describe in detail how the system components are implemented. While the notion of building is the activity of creating or replacing or improving existing systems both in whole or in part ${ }^{7}$.

This research is a descriptive study using quantitative research method, namely research by finding information about existing symptoms, clearly defined objectives to be achieved, planning how to approach it, and collecting data as material for making reports. In this study the authors wanted to know the effectiveness of learning based on program learning (PBL) with online learning learning method for students of the Faculty of Dental Medicine, Universitas Airlangga. The research variables that will be examined in this study are divided into two variables namely, the dependent variable (X) consisting of one variable, namely the perception of Faculty of Dental Medicine Universitas Airlanggastudents about the effectiveness of PBL learning while the independent variable $(\mathrm{Y})$ consists of one variable, the online learning method.

The research location is a place or region where the research will be conducted. Research activities certainly require a location that will be used as a background to obtain the data needed to support the achievement of research objectives. Determination of the location of this study related to the presence of data or information in accordance with the objectives of the study. The research conducted took place at the Faculty of Dental Medicine Universitas Airlangga, Surabaya City. This research was conducted for approximately two weeks.

Data collection method is one aspect that plays a role in the smoothness and success in a study. In this study the data collection method used was a questionnaire or questionnaire. Questionnaire or questionnaire is a data collection technique through forms that contain questions submitted in writing to a person or group of people to get answers or responses and information needed by researchers ${ }^{8}$. This study uses a questionnaire or questionnaire, the list of questions is structured with the form of multiple choice questions (Multiple Choice Questions) and closed questions (Close Question).

The population is the whole subject of research. If someone wants to examine all elements in the research area, then the research is a population study or population study or census study. Population is a generalization area consisting of objects or subjects that have certain qualities and characteristics determined by researchers to be studied and then drawn conclusions ${ }^{5}$. The population of our study was preclinical students of the Faculty of Dental Medicine Universitas Airlangga, which consisted of batches of 2016, 2017, 2018 and 2019.

The sample is part of the number and characteristics possessed by the population. If the population is large, and researchers may not study everything in the population, for example due to limited funds, manpower, and time, then researchers can use samples taken from that population. What is learned from the sample, the conclusion can be applied to the population. For that the sample taken from the population must be representative or represent ${ }^{5}$. 
Sample Formula:

$$
n=\frac{4 \cdot z_{\alpha}^{2} \bullet \pi \bullet(1-\pi)}{W^{2}}
$$

\section{Note:}

$\pi=$ the proportion of events/prevalence rates if unknown is considered to be $50 \%=0,50$

$\mathrm{W}=$ width of deviation $($ maximum $=10-20 \%=0,1-0,2)$

$\alpha=0,05 \mathrm{w} \mathrm{z}$ (adjusted SD) $=1,96$

From this formula, the sample size is 38,416 . A study can be said to be valid if the number of samples can represent the population. So, it can be concluded that in order for this study to be valid, the minimum number of samples that we had to get to the preclinical students of the Faculty of Dental Medicine, Universitas Airlanggawas 39 samples.

In the process of this study, data collection was obtained by distributing questionnaires related to emotional responses to respondents to be investigated, namely Universitas Airlangga Faculty of Dental Medicine students. The research instrument used was a questionnaire or google questionnaire using the Likert scale. Likert scale is a measurement scale developed by Likert and has 4 or more items of a question that are combined to become a score/value that represents the nature of an individual, including knowledge, attitudes and behavior 9 .
Likert scale will be used with the aim of evaluating the implementation of educational programs by analyzing the perceptions of students who have followed and run an existing education program at the Faculty of Dental Medicine, Universitas Airlangga, namely Problem Based Learning (PBL) using online learning method. The research instrument used was a questionnaire or questionnaire with the following scores:very effective (score 5), effective (score 4), no opinion (score 3), not effective (score 2), and very ineffective (score 1)

In this study, data analysis that can be done is descriptive data analysis. Descriptive data analysis is performed as the first stage for further data analysis, but if the research form does not include random research or analytic research, only descriptive data analysis can be carried out on the data that has been collected. In this data analysis, the data will be packaged in the form of frequency tables, along with mean, median, and mode tables. Data in the form of scores will be arranged with the percentage of survey responses from the lowest to highest scores in the table.

\section{Result}

To obtain data from a distribution of at least 100 questionnaires, the research was conducted online which was directed directly to undergraduate education students in semester 1, 3, 5 and 7 of the Faculty of Dental Medicine, Universitas Airlangga, Surabaya, who were undergoing PBL classroom education using online learning method.

Table. 1. Cross tabulation of respondents' characteristics distribution and the effectiveness of PBL classes with online learning method.

\begin{tabular}{|l|c|c|c|c|c|c|}
\hline \multirow{2}{*}{ Respondents Characteristic } & \multirow{2}{*}{ Total \% } & \multicolumn{5}{|c|}{ Effectiveness of PBL classes with online learning method (\%) } \\
\cline { 3 - 7 } & & Effective & Very Effective & Idle & Ineffective & Very Ineffective \\
\hline Gender & & & & & & \\
Male & 15,5 & 56,2 & 0,0 & 18,8 & 25,0 & 0,0 \\
Female & 84,5 & 51,7 & 6,9 & 13,8 & 24.1 & 3,4 \\
\hline Class of Study & & & & & & \\
2016 & 24,3 & 40,0 & 8,0 & 20,0 & 28,0 & 4,0 \\
2017 & 26,2 & 44,4 & 0,0 & 18,5 & 33,3 & 3,7 \\
2018 & 25,2 & 65,4 & 7,7 & 0,0 & 26,9 & 0,0 \\
2019 & 24,3 & 60,0 & 8,0 & 20,0 & 8,0 & 4,0 \\
\hline Media & & & & & & \\
All & 1,0 & 100 & 0,0 & 0,0 & 0,0 & 0,0 \\
Smartphone & 57,3 & 52,5 & 3,4 & 18,6 & 22,0 & 3,4 \\
Smartphoneand Laptop & 1,0 & 0,0 & 0,0 & 0,0 & 100 & 0,0 \\
Laptop & 33,0 & 52,9 & 8,8 & 11,8 & 23,5 & 2,9 \\
Laptop and textbook & 1,0 & 0,0 & 100 & 0,0 & 0,0 & 0,0 \\
textbook & 6,8 & 57,1 & 0,0 & 0,0 & 42,9 & 2,9 \\
\hline
\end{tabular}


The number of preclinical students in semester 1, 3, 5, and 7 of the Facultyof Dental Medicine of Universitas Airlangga, Surabaya who are more female (84\%) compared to male students $(15.5 \%)$, this can be seen from table 1 .

This study was aimed at the four youngest batches at the Faculty of Dental Medicine, Universitas Airlangga, Surabaya, namely the batch of 2016, 2017, 2018 and 2019. From the number of respondents participating in each class, the highest percentage was found in the 2017 class of $26.2 \%$, followed by class of 2018 that is equal to $25.2 \%$. As for the 2016 and 2019 batches they have the same percentage of $24.3 \%$. From these results it can be concluded that the majority of respondents were from the class of 2017 and the lowest respondents in the class of 2016 and 2018.

From the data table above illustrates that the media most widely used by respondents are "Smartphones" $(57.3 \%)$, and the least used media by respondents are "Smartphones and Laptops" (1.0\%) and "Laptops and textbooks "(1.0\%). From this data it can be concluded that respondents use smartphones more, and rarely use other online media in PBL classes.

Online learning based PBL classes implemented at Dental Medicine, Universitas Airlanggahave been considered effective by respondents to support learning during lectures. This can be seen from the table data above that the percentage of respondents considers effective PBL-based online learning classes that is equal to $52.4 \%$ and very effective $5.8 \%$, very ineffective $2.9 \%$, no opinion $14.6 \%$, and ineffective $24.3 \%$.

\section{Discussion}

This research is a survey conducted in the area of the Faculty of Dental Medicine of Universitas Airlangga regarding students' perceptions of the effectiveness of the Problem Based Learning (PBL) class using online learning method. The purpose of this study was to determine the effectiveness of the Problem Based Learning (PBL) class using online learning method in Universitas Airlangga Faculty of Dental Medicine students. This research also has benefits, namely as a basis for perfecting the Problem Based Learning (PBL) program in various universities in Indonesia.

In this study shows that the most widely used media by respondents for online learning in the Problem Based Learning (PBL) class is "smartphone" which is $57.3 \%$ followed by "laptops" by $33.0 \%$, "textbooks" by $6,8 \%$, "smartphones and laptops" by $1.0 \%$, and "textbooks and laptops" by $1.0 \%$. This is due to a survey conducted by the Indonesian Internet Providers Association, showing nearly half of internet consumers prefer smartphones or tablets.

A survey conducted in 2017 involving 2,500 responses showed $44.16 \%$ of them claimed to access the internet through a smartphone or tablet, while $4.49 \%$ claimed to access cyberspace through computers or laptops. The survey was corroborated by the percentage of smartphone or tablet ownership which reached $50.08 \%$ in Indonesia. Only $25.72 \%$ of the internet users in Indonesia who have a computer or laptop ${ }^{10}$.

In addition, this study also showed that the number of students at the Faculty of Dental Medicine at Universitas Airlanggawas dominated by the female population compared to men as indicated by the results of respondents who filled out the questionnaire. The amount can be accumulated in the form of percent, $84.5 \%$ for women and $15.5 \%$ for men. The sexes also differ in terms of attention, ability, views and others. This can be due to the influence and nature of the tradition on the sex. It is this physical and psychological state that can influence differences in perceptions between women and men.

In this study, it showed that Universitas Airlangga Faculty of Dental Medicine students who considered online Problem Based Learning (PBL) classes effective $52.4 \%, 5.8 \%$ highly effective, $2.9 \%$ highly ineffective, no opinion $14.6 \%$, and ineffective $24.3 \%$. This is because Problem Based Learning (PBL) can stimulate open-mindedness and encourage students to do more critical and active learning because they are invited to learn through problems that arise and how to solve these problems. Automatically students get knowledge as well as how to apply it. The Problem Based Learning (PBL) method also challenges students so that they can get satisfaction by discovering new knowledge for themselves through online learning method ${ }^{11}$.

This study shows that the number of students of the Faculty of Dental Medicine, Universitas Airlangga has many correspondents that are almost the same for each generation. There were 25 correspondents from the class of 2016, 27 correspondents from the 2017 class, 26 correspondents from the class of 2018, and 25 correspondents from the class of 2019. Most of the 
correspondents filled out the questionnaire of their own volition, filling in the questionnaire online. However, the possibility of differences in the amount of participation per class is also related to differences in free time and willingness to fill in the existing questionnaire.

\section{Conclusion}

The majority of Universitas AirlanggaFaculty of Dental Medicine students have a perception that Problem Based Learning (PBL) using the Online Learning method is effectively to apply.

Conflicts of Interest: There are no conflicts of interest.

Source of Funding: Self-Funding

Ethical Clearance: Approved

\section{Reference}

1. Alrahlah A. How effective the problem-based learning (PBL) in dental education. A critical review [Internet]. Vol. 28, Saudi Dental Journal. Elsevier B.V.; 2016. p. 155-61. Available from:/ pmc/articles/PMC5110467/?report=abstract

2. Arends RI. Learning to Teach. Seventh Ed. New York: McGraw-Hill; 2007.

3. Ayub M, Saleem MA. A Speech Recognition Based Approach for Development in $\mathrm{C}++$. Int $\mathrm{J}$ Comput Sci Issues. 2013;10(1):52-6.
4. Indonesia Medical Council. Standar Kompetensi Dokter Gigi Indonesia. 2015.

5. Sugiyono. Metode Penelitian Kuantitatif, Kualitatif dan R \& D. Bandung: Afabeta; 2011.

6. Tika MP. Metode Penelitian Geografi. Jakarta: PT. Bumi Aksara; 2005.

7. Roger S P. Rekayasa Perangkat Lunak Pendekatan Praktisi (Buku Satu). Yogyakarta: ANDI Yogyakarta; 2002.

8. Mardalis. Metodologi Penelitian: Suatu Pendekatan Proposal. Jakarta: Bumi Aksara; 2008.

9. Maryuliana, Subroto, I.M.L., \& Havian SFC. Sistem Informasi Angket Pengukuran Skala Kebutuhan Materi Pembelajaran Tambahan Sebagai Pendukung Pengambilan Keputusan di SMA Menggunakan Skla Likert. Universitas Islam Sultang Agung; 2016.

10. Indonesian Internet Service Provider Association. Potret Zaman Now Pengguna dan Perilaku Internet Indonesia. APJII; 2018. 1-7 p.

11. Leonardus B. Penerapan Model Problem Based Learning untuk Meningkatkan Keaktifan dan Hasil Belajar Siswa Pada Pelajaran Komputer Di SMKN 2 Wonosari Yogyakarta. Fakultas Teknik. Univesitas Negeri Yogyakarta: Yogyakarta.; 2013. 